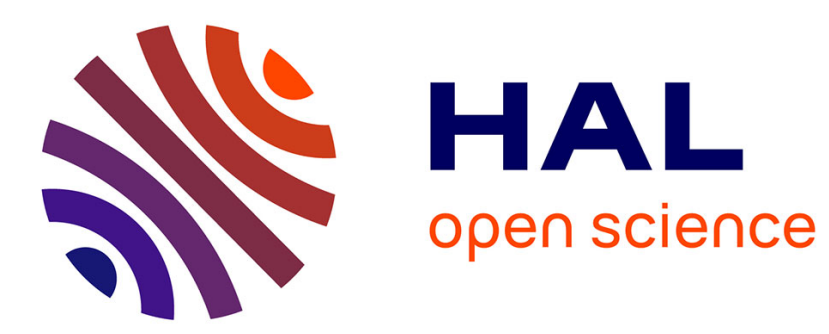

\title{
Anthracological analysis of fuel wood used for firesetting in medieval metallic mines of the Faravel district (southern French Alps) \\ Vanessa Py, Aline Durand, Bruno Ancel
}

\section{- To cite this version: \\ Vanessa Py, Aline Durand, Bruno Ancel. Anthracological analysis of fuel wood used for firesetting in medieval metallic mines of the Faravel district (southern French Alps). Journal of Archaeological Science, 2013, 40, pp.3878-3889. 10.1016/j.jas.2013.05.006 . hal-01092842}

\section{HAL Id: hal-01092842 \\ https://hal.science/hal-01092842}

Submitted on 9 Dec 2014

HAL is a multi-disciplinary open access archive for the deposit and dissemination of scientific research documents, whether they are published or not. The documents may come from teaching and research institutions in France or abroad, or from public or private research centers.
L'archive ouverte pluridisciplinaire HAL, est destinée au dépôt et à la diffusion de documents scientifiques de niveau recherche, publiés ou non, émanant des établissements d'enseignement et de recherche français ou étrangers, des laboratoires publics ou privés. 


\title{
Anthracological analysis of fuel wood used for firesetting in medieval metallic mines of the Faravel district (southern French Alps)
}

\author{
Vanessa Py ${ }^{\mathrm{a}, *}$, Aline Durand ${ }^{\mathrm{b}}$, Bruno Ancel ${ }^{\mathrm{c}, \mathrm{d}}$ \\ ${ }^{a}$ GEODE, UMR 5602, CNRS, Université de Toulouse II-Le Mirail, Maison de la Recherche, 5 Allées Antonio Machado, 31058 Toulouse Cedex 1, France \\ ${ }^{\mathrm{b}}$ LA3M (ex LAMM), UMR 7298 (ex UMR 6572), CNRS, Université d'Aix-Marseille, MMSH, 5 rue du château de l'Horloge, BP 647, 13094 Aix-en-Provence, France \\ ${ }^{\mathrm{c}}$ TRACES, UMR 5608, CNRS, Université de Toulouse II-Le Mirail, Maison de la Recherche, 5 Allées Antonio Machado, 31058 Toulouse Cedex 9, France \\ ${ }^{\mathrm{d}}$ Service Culturel Municipal de L'Argentière-La Bessée, Mairie de L'Argentière, 05120 L'Argentière-La Bessée, France
}

\section{A R T I C L E I N F O}

\section{Article history:}

Received 31 May 2012

Received in revised form

24 April 2013

Accepted 5 May 2013

\section{Keywords:}

Mining

Firesetting

Fuel wood

Charcoal analysis

Timbershed

Middle Ages

French southern Alps

\begin{abstract}
A B S T R A C T
This anthracological study of fuel wood used in the Faravel mines is part of a doctorate research programme conducted on the interrelationship between mines and forests of the Southern Alps during the Middle Ages. The study area is situated in the upper Durance valley, a major mining region from the 11 th to the end of the 13th century. Man sought and extracted silver-bearing ore from the valley bottoms to the summit of the mountains. He employed firesetting to attack the hard gneiss bedrock. The study of residual charcoal has been used to measure the impact of the mining economy on the development of mountain forests. The example of the small district of Faravel situated in an upper mountainous region (1900-2150 m altitude), illustrates a supply anchored at subalpine level with a gradual extension of the source area towards the timberline. The anthracological spectra document extinction of Pinus cembra L. at subalpine level and the lowering of the upper limit of the dense forest dominated by Larix decidua Mill. These changes are the result of agropastoral and mining pressure, as testified by both surviving manuscripts and archaeology.
\end{abstract}

(c) 2013 Elsevier Ltd. All rights reserved.

\section{Introduction}

The southern French Alps are less well-known as a mining region than the central eastern Alps. Silver, which was mainly used for minting coins, was the reason for the expansion of mining activity during the medieval period. The principal metal-rich areas are the Upper Durance (Hautes-Alpes), the valleys of the Roya and the Tinée (Alpes-Maritimes) and the Maures massif (Var) (Ancel, 2010). In the vast majority of mines, firesetting was used to fracture the rock surface and extract the ore. This technique, known and used since prehistoric times, was used until the 19th century in the mines of northern Europe (Berg, 1992; Py et al., 2012; Timberlake, 1990; Weisgerber and Willies, 2001; Willies, 1994). Notorious for its wood consumption, this method of mining has been described as a major factor in the deforestation of the Southern Alps during the Middle Ages. However, thanks to the development of mining archaeology, anthracology has emerged as an effective approach to detailed understanding of the effects of the mining industry on southern Alpine forests. During the 1990s, the

\footnotetext{
* Corresponding author. Tel.: +33 6623177 31; fax: +33 561504275

E-mail addresses: vanessa.py@univ-tlse2.fr, vpy@univ-tlse2.fr (V. Py).
}

palaeological and palaeo-ethnobotanical potential of charcoal produced by firesetting has since been highlighted (Castelletti and Castiglioni, 1993; Dubois, 1996). But the study of mines is a complicated affair. Access is often difficult, and as a consequence their study has remained marginal and of little depth, and has only been punctuated by recent development since the 2000s (Heiss and Oeggl, 2008; Ludemann, 2010; Pichler et al., 2011; Téreygeol and Dubois, 2003). At Faravel, archaeological excavations have applied the sampling anthracological protocol developed and tested in the Fournel silver mines (Py, 2006; Ancel et al., 2010). Here, with the assessment of a small-scale mining area, anthracology allows us to consider the state and composition of the exploited woodlands and their evolution from the 10th to the end of the 13th century. This paper aims to contribute in restoring the complex history of the south Alpine forests and their upper limit. Moreover, it provides new elements on subalpine woodland management for mining activities during the High Middle Ages.

\section{Study area: location, bio-geography, current vegetation and geology}

The Faravel district is situated at an altitude of $1900-2150 \mathrm{~m}$, in the upper valley of the Byaisse (Freissinières, Hautes-Alpes, France) 


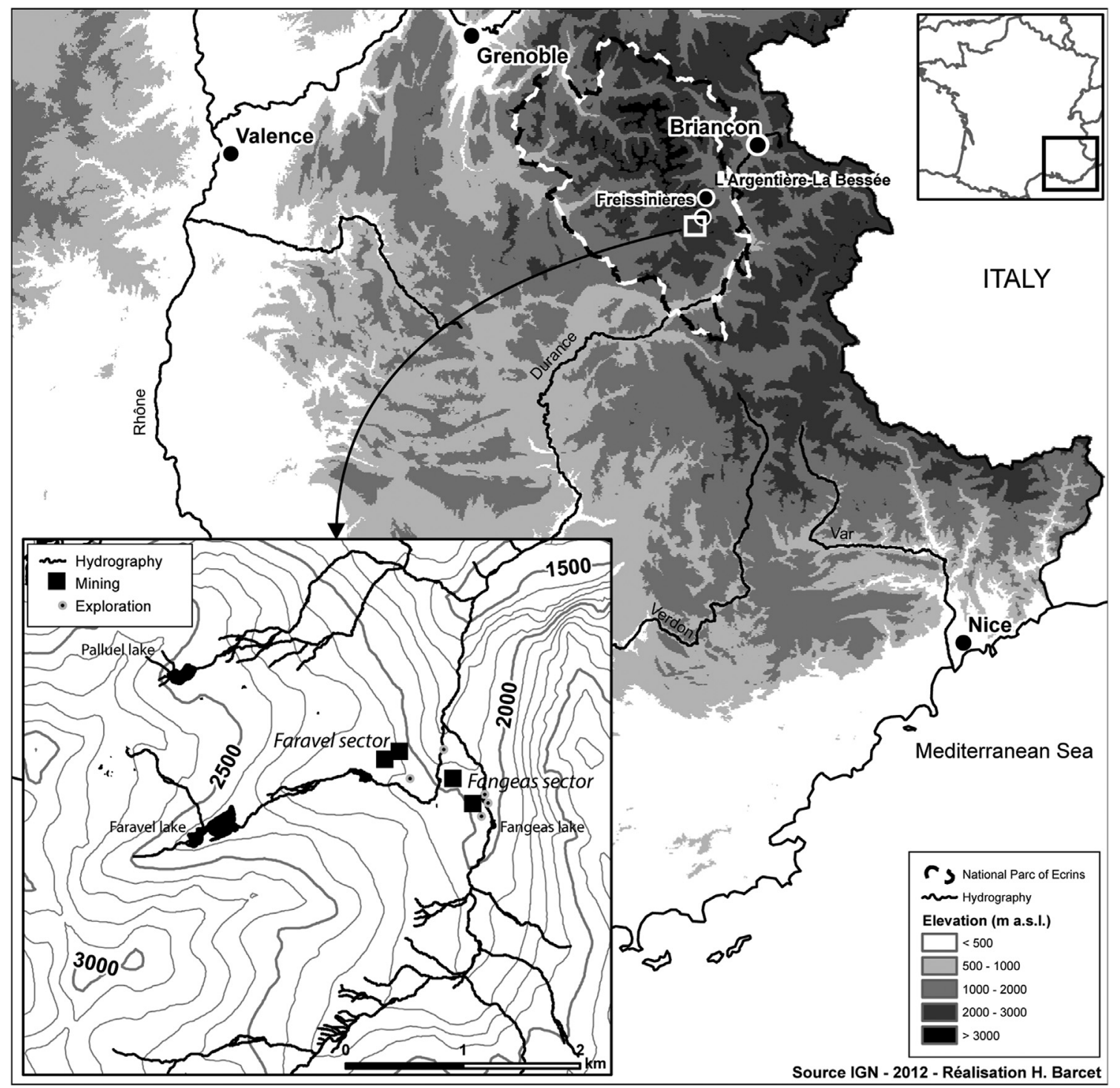

Fig. 1. Location map of French southern Alps and regional location map of the study area (upper Byaisse valley). Location of mining sectors in the upper Byaisse valley.

(Fig. 1), being a part of the central zone of the Ecrins National Park and stretching across the altitudinal limits of the subalpine level (from 1700 to 2200-2400 m) of the intra-alpine zone of the Alps. In the study area, subalpine level corresponds with Arolla pine and European larch series distribution area, for which the optimum altitude is between 1750 and $2100 \mathrm{~m}$ (Ozenda, 1985). After glacial retreat this area became forested and very soon was subject to the impact of early human activity (de Beaulieu, 1977; Nakagawa, 1998; Tessier et al., 1993; Wegmüller, 1977). Today, it is mainly occupied by larch forests that dominate the majority of north-facing slopes and are absent from the xeric south-facing slopes where pines (Pinus sylvestris L., Pinus uncinata Mill. ex Mirb.) and heathland are present.

The main mining works are scattered between the glacial rock bars of Faravel and Fangeas lakes. The mining district consists of two major sectors called Faravel and Fangeas (Fig. 1). The Faravel sector is located at an altitude of $2070-2150 \mathrm{~m}$, on a gneissic dome plateau which dominates the Pont du Fer stream (Figs. 1-3, view 1). The surrounding landscape is almost devoid of trees (Fig. 3, view 1), typical of the Kampfzone stretching between the forest line and the treeline. Today's moderate pastoral activity has changed the potential and natural limits of its extension. Despite the fact that altitudinal conditions are not prohibitive to its development, the virtual exclusion of larch shows evidence of strong pressure exerted by humans over the past centuries. The dominant vegetation consists of subalpine grassland and more or less extensively scattered shrubbery. The Ericaceae heathlands (Rhododendron ferrugineum L., Vaccinium myrtillus L., Vaccinium vitis-idaea L. and Vaccinium uliginosum L.) occupy the north-facing slopes whereas the juniper and bearberry heathlands occupy the south-facing slopes (Juniperus sabina L., Juniperus communis L. subsp. nana W. and Arctostaphylos uva-ursi L.). The Fangeas mines are mainly located just downstream of the small Fangeas lake, on the left bank of the Oules river, between 1970 and $2000 \mathrm{~m}$ altitude (Figs. 1 and 2). Further downstream, at approx. $1900 \mathrm{~m}$ altitude, work faces have been identified on the Pont du Fer stream banks. Currently, the works are located at the upper limit of the subalpine larch forest (larch wood pasture) composed of young pioneer larch and shrubberies of rusty-leaved alpenrose ( $R$. ferrugineum $L$.) in the undergrowth (silvatic rhododendron heathland).

The minerals extracted by the medieval miners (mainly PbS$\mathrm{Ag}$ ) were sunken in the crystalline basement of the cortical zone of 


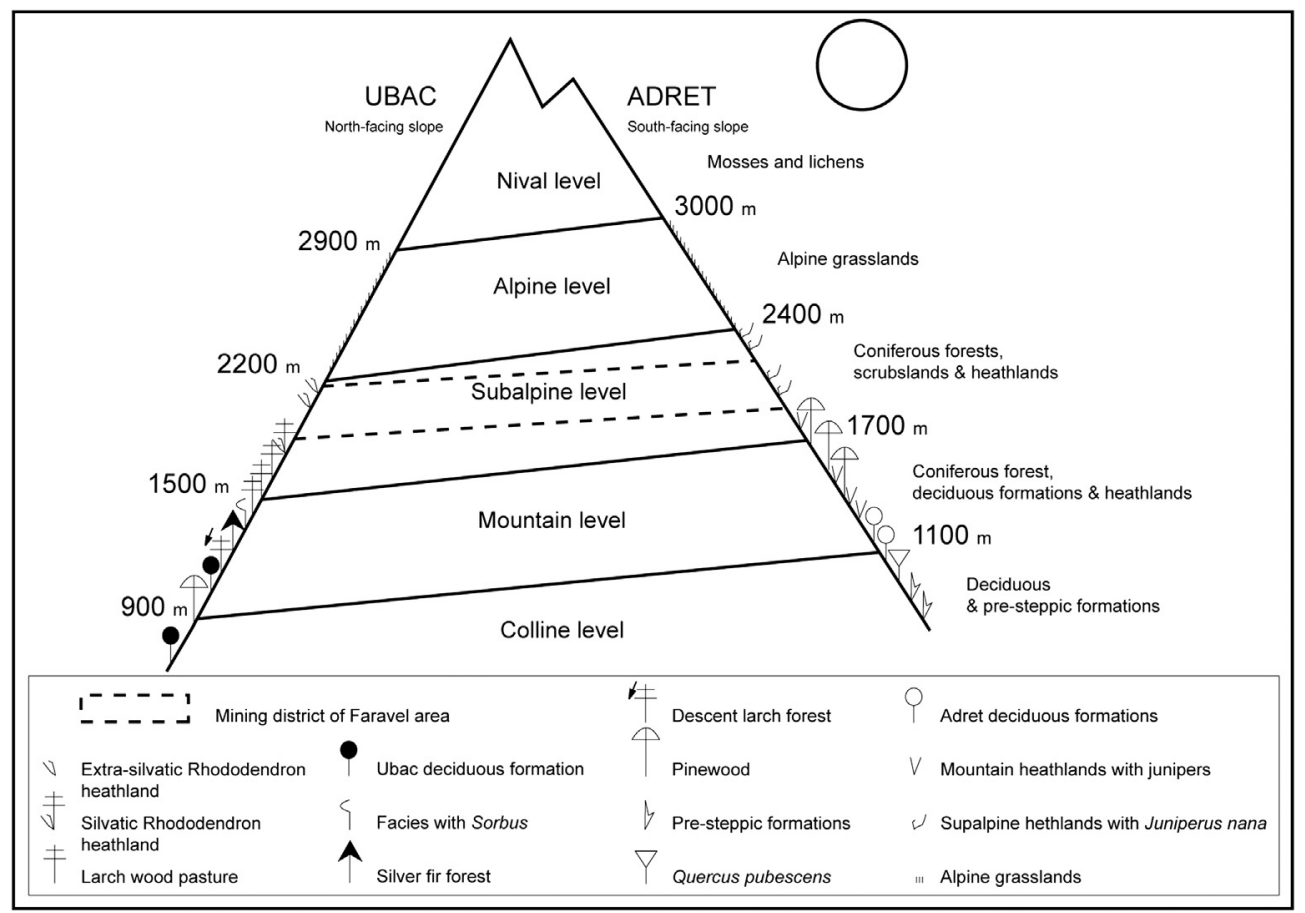

Fig. 2. Pattern of vegetation current vertical zoning with location of the area concerned by the Faravel district.

the Ecrins massif which is composed of gneiss and quartz. The substrates are dominated by siliceous formations.

\section{Archaeological and historical background}

Because of the mention of "argenteria de Faravello" in a papal bull dating from 1169, this small mining district was attributed to the medieval era. Re-examination of the few surviving texts in modern transcriptions show that since at least the 11th century, the archbishops and the Embrun church chapter and a local noble family shared this property and its income (Py, 2009; I, 134-181). The in-depth archaeological study of the Faravel district was carried out in 2003 (Py and Ancel, 2007). Excavations revealed the layout of the exploited ore vein by means of scraping, metric-sized trenches and opencast pits of which the deep parts were sunken in (Fig. 3, views $1,2,3$ ). Their smooth and concave walls and the charcoal preserved in the backfill indicate usage of firesetting. In the Faravel II mining research trenches, a fire layer rich in charcoal and sealed by a detrital layer has been identified. This charcoal-rich layer corresponds to a fire (natural or anthropic ?) which appears simultaneously to the extraction phase or even just succeeding it. At Fangeas, the excavation of a subvertical site (Great Pit, Fangeas II) and an extraction well (Great Well, Fangeas I) that was almost completely flooded and sunken in, revealed numerous perfectly preserved items of timbering and shoring (Py, 2010) (Fig. 3, plate 4). Excavations were also conducted on the edges of the mouth of the well $\left(50 \mathrm{~m}^{2}\right)$, uncovering an area of mechanical preparation, attested to by the presence of an anvil.

\section{Materials and methods}

\subsection{Sampling protocol}

Sampling was conducted to collect deposits that provide information covering the different phases of mining activity. The protocol relies on good control of the relative chronology of the mining works and sediment accumulation within the mine (Py, 2006, 2009, I, 265-388). The origin and history of the deposits and the duration of the activity that has been recorded was considered. In the waste heaps, filled-up trenches, pits, or galleries, the sampling strategy was controlled by stratigraphic analysis. Within the limits of an excavation or archaeological test pits, 10-30 L of material from each layer (or Stratigraphic Unit or SU) containing charcoals have been sampled every metre and directly in stratigraphic sections erected every metre (Fig. 4). Still within the limits of the excavated area, the circulation layers bearing very thin and compact have been entirely sampled because charcoals dispersed in these layers offer a good synthesis of firewood used during an extraction phase (Py, 2009; I, 351-365). To minimize charcoal fragmentation, all samples were subjected to flotation in a column of 6 and $4 \mathrm{~mm}$ sieves. All charcoals found in the two sieves were collected and thoroughly dried avoiding direct sunlight and heat to prevent damage and infestation by fungi. The largest fragments most likely to disintegrate were isolated from the rest of the sample to avoid statistical errors. A total of 42 samples associated with an archaeological layer were taken.

\subsection{Anthracological analysis}

In a domestic context, the quantity of charcoals generally considered to be required per layer (or SU) lies between 250 and 400 charcoals (Chabal, 1997; Théry-Parisot et al., 2010). In a mining context, it is considered to be lower: a minimum of 100-150 charcoal pieces per SU is required from the backfill and filling up from mining works and a minimum of 200 charcoals is necessary from the circulation layers (Py, 2006, 2009, I, 346-388). Anthracological analysis was carried out using reflected light microscopy (Jacomet and Kreuz, 1999; Schweingruber, 1982). The three anatomical planes were observed with magnifications at 100, 200 and 500 times. They were compared with data from xylology atlases (Greguss, 1959; Schweingruber, 1978, 1990; Vernet et al., 2001) and reference collections of the University of Aix-Marseille (LA3M, UMR 

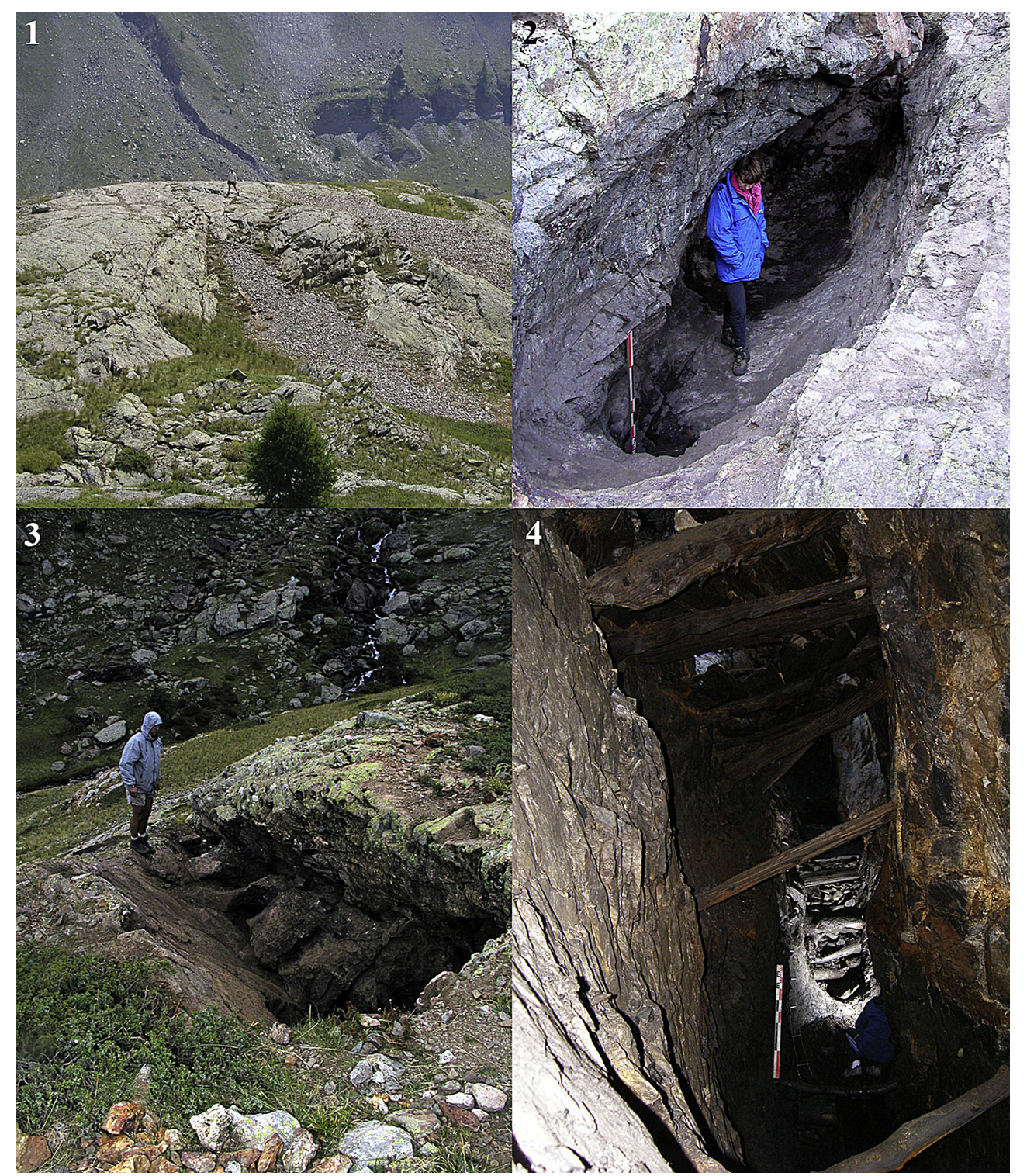

Fig. 3. Views of mine working: 1) View of waste heap of the Faravel I mines, west slope; 2) Faravel I west pit (excavated); 3) Trench research (excavated) Faravel II; 4) Big pit of Fangeas II with wood floor and shores up.

7298 and IMEP, UMR 6116) and Montpellier II (CBAE, UMR 5059). The information obtained is expressed by relative frequency spectra (\%) of all identified taxa for the different levels. In addition, for measuring the palaeoecological reliability of different deposits or to characterize a selection of taxa for mining, Pareto's concentration index was systematically calculated. The chrono-stratigraphy of the deposits guided the construction of the anthracological synthesis diagram which supports the palaeoecological and ethnobotanical interpretations (Fig. 5).

The microscopic study of charcoal led to recurring observations of threads of charred mycelium (hyphae). Evidence on fungal infestation before charring was observed as alterations to the wood tissues microstructure, and as hyphae remains themselves. Bearing in mind the precautions taken during the drying of the samples and their storage, no modern fungal infestation needed to be taken into account (Badal, 2004; Moskal-del Hoyo et al., 2010; Théry-Parisot, 2001). The presence of fungal hyphae can be used as an indicator of either the use of diseased trees, or of partly rotten dead wood, or of badly stored timber. In each fragment analysed, the presence of infestation was sought in the three anatomical planes, particularly in the radial and tangential planes where hyphae are more easily visible. It was therefore possible to estimate their average frequency in the different deposits studied (Fig. 6).

Due to the overall very low particle sizes of charcoal fragments, the estimation of wood diameters using growth-ring curvature was not possible. Here, to understand the morphology of the selected wood qualities used as firewood, the frequency of charcoal fragments with compression wood was evaluated. Indeed, the study material lends itself to this approach because it comes from subalpine level where the dominance in coniferous taxa was expected. In the transverse plane, compression wood results in a morphological change of cells (rounder and wider lumens) and in the radial plane, in microfibrils (Schweingruber, 1990). Compression wood is produced on the underside of inclined trunks or branches to enable themselves to straighten up. Its volume depends mainly on three stem form variables: the overall inclination, local inclination and eccentricity of the pith (Hapca, 2004). Also, compression wood is most often located in large lower branches and non-linear trunks. Its proportion increases with the overall inclination of the trunk. 


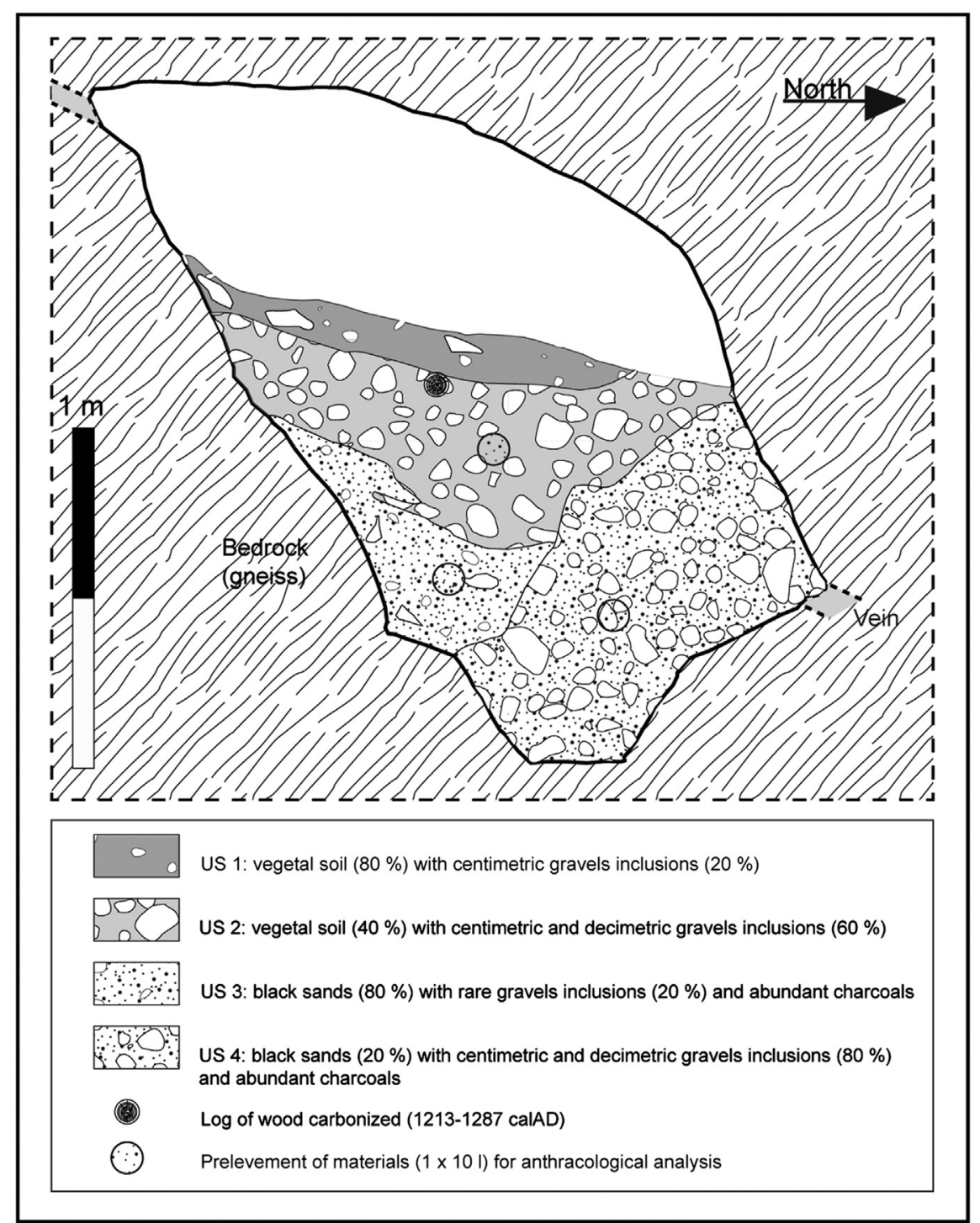

Fig. 4. Example of a stratigraphic cut realised in the backfills and localisation of anthracological samples.

\subsection{Dating method}

Due to the absence of archaeological material enabling dating of the excavated layers and features, absolute dating of mines required the use of radiocarbon analysis. In a medieval mining context, the conventional scintillation method is adapted to the type of samples. We combined the material from several fragments for each single dating, in order to get a more representative date for each dated deposit, and to avoid too strong a bias by singular charcoal intrusions from other layers. Wherever possible, the charcoals from twigs and young saplings or from the most recent growth rings of a big branch or more mature trunk was selected. Nine conventional radiocarbon dates were produced by the Centre for radiocarbon dating of the University Claude Bernard Lyon 1 (Ly laboratory code). In addition, a fragment of charred Juniper branch found in a scraping backfill was measured by AMS dating by the Poznan dating laboratory (Poz laboratory code). Indeed, for this layer, the quantity of charcoal sampled was not enough large to make a conventional radiocarbon date. All dates have been calibrated against the IntCal09 data set (Reimer et al., 2009) using the program OxCal v4.2.2 Bronk Ramsey, 2009. The relative chronology of mining works and their filling up is based on the study of their stratigraphy and on the analysis of their operational dynamics. The phasing of radiocarbon and archaeological data leads to the characterisation of mining phasing. Moreover, it is reinforced by dendrochronological dating of mining timber and wooden artefacts which will soon be published.

\section{Results}

\subsection{Chronology of mining works}

Radiocarbon analyses confirm the medieval dating of these mines. Activity became more widespread from the 10th century to the second half of the 13th century (Table 1). Operation of the Faravel II and Fangeas I outcrops began in the 10th century. It is simultaneous with the fire episode mentioned earlier and for whose origin is discussed further on. During the 11th century, the exploitation of the western slope of Faravel I (West pit) and the Fangeas II vein (Great pit) begins. Major subvertical excavation sites of Faravel I and Fangeas (I and II) were exploited from the second half of the 11th century to the second half of the 12th century. A new research episode took place during the first half of the 13th century on the eastern slope of Faravel I. Taking into account the 


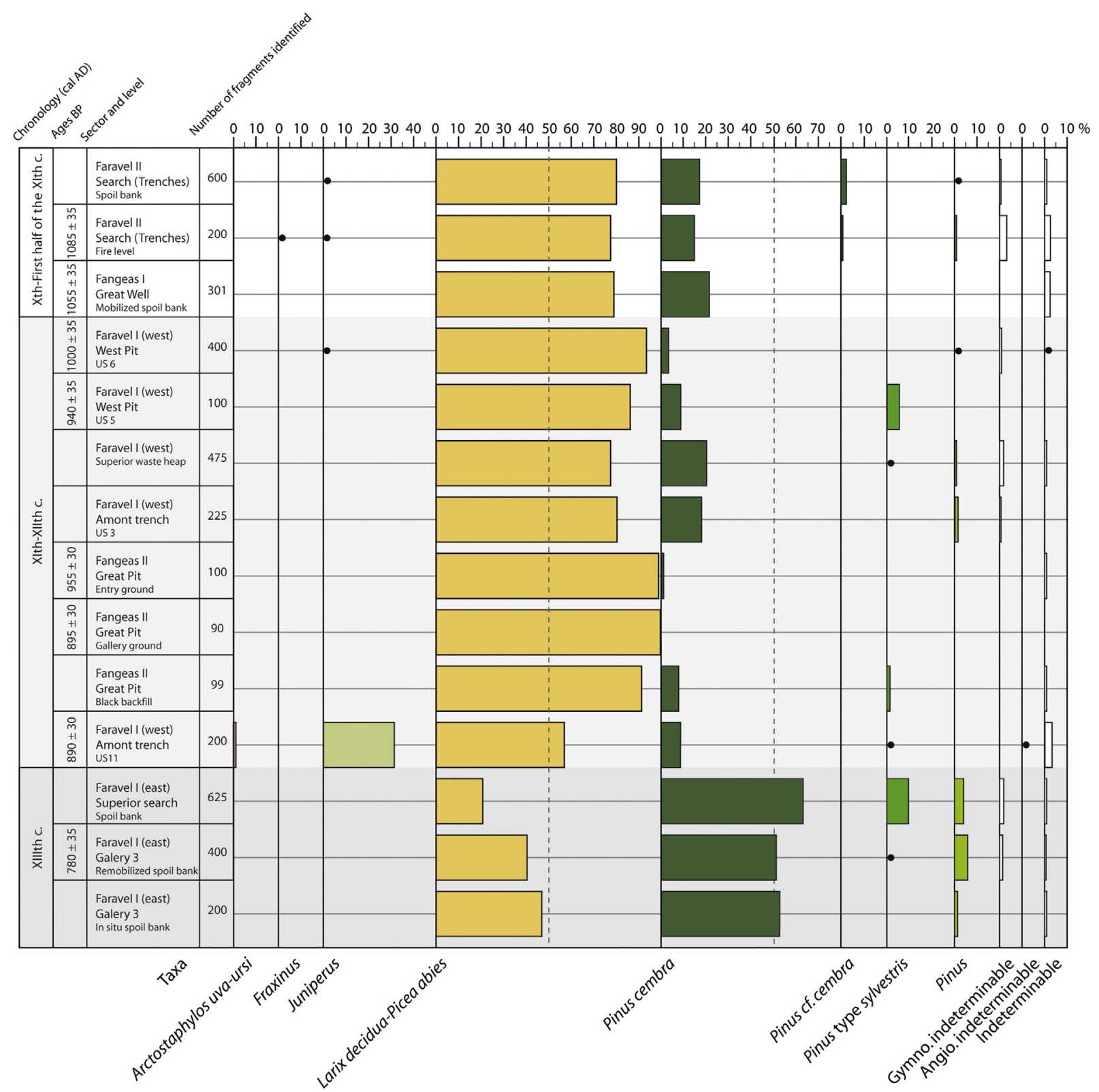

Fig. 5. Percentage anthracological diagram of synthesis. Charcoals sampled in same levels are counted together. For each level, number of fragments counted and identified is shown in the fourth column. Bars express relative frequencies of taxa. They are expressed as a percentage. Little black points indicate relative frequency $\leq 0.5 \%$. Spectra ordered according to the chrono-stratigraphy are organized in anthracological diagram of synthesis.

small scale of discovered mines, this chronology presupposes that the activity probably seasonal, was highly fragmented, punctuated by both periods of research - that were not always successful - and by phases of intense activity accompanied by the exploitation of worksites.

\subsection{Taxa and their proportions}

A total of 4134 charcoal fragments were analyzed and only eight taxa were identified: A. uva-ursi, Fraxinus angustifolia subsp. oxycarpa/excelsior/ornus, Juniperus, Larix decidua/Picea abies, Pinus cembra, Pinus cf. cembra, P. cembra/type sylvestris and Pinus type sylvestris (Fig. 5).

A. uva-ursi was identified in one deposit (Faravel I, western slope, upstream trench) and its frequencies are trivial (1\%). Fraxinus excelsior being the only ash that can survive at $2000 \mathrm{~m}$ altitude, its presence is thus more likely than other species of the genus. It has been identified only once in Faravel II (fire level). The Juniperus taxa may include at least five taxa which are impossible to differentiate by comparative anatomy (J. communis L. subsp. communis, J. communis L. subsp. nana Willd., J. sabina L. and Juniperus thurifera L.). Its frequencies are anecdotal (less than 1\%) except in the upstream trench at Faravel I (west slope) where they reach 31.6\%. The anatomic uncertainty between $L$. decidua and Picea abies has resulted in the taxon Larix europea/Picea abies. However, biogeographic, ecological and paleoecological data argue for the unique presence of $L$. decidua. This taxon is widely prevalent in almost all sampled deposits, except those from the east slope of Faravel I where it is replaced by P. cembra. Furthermore, P. cembra is secondary and its frequencies are always lower than $20 \%$. The inability to differentiate $P$. sylvestris and $P$. uncinata through comparative anatomy (Schweingruber, 1990) resulted in the taxon 


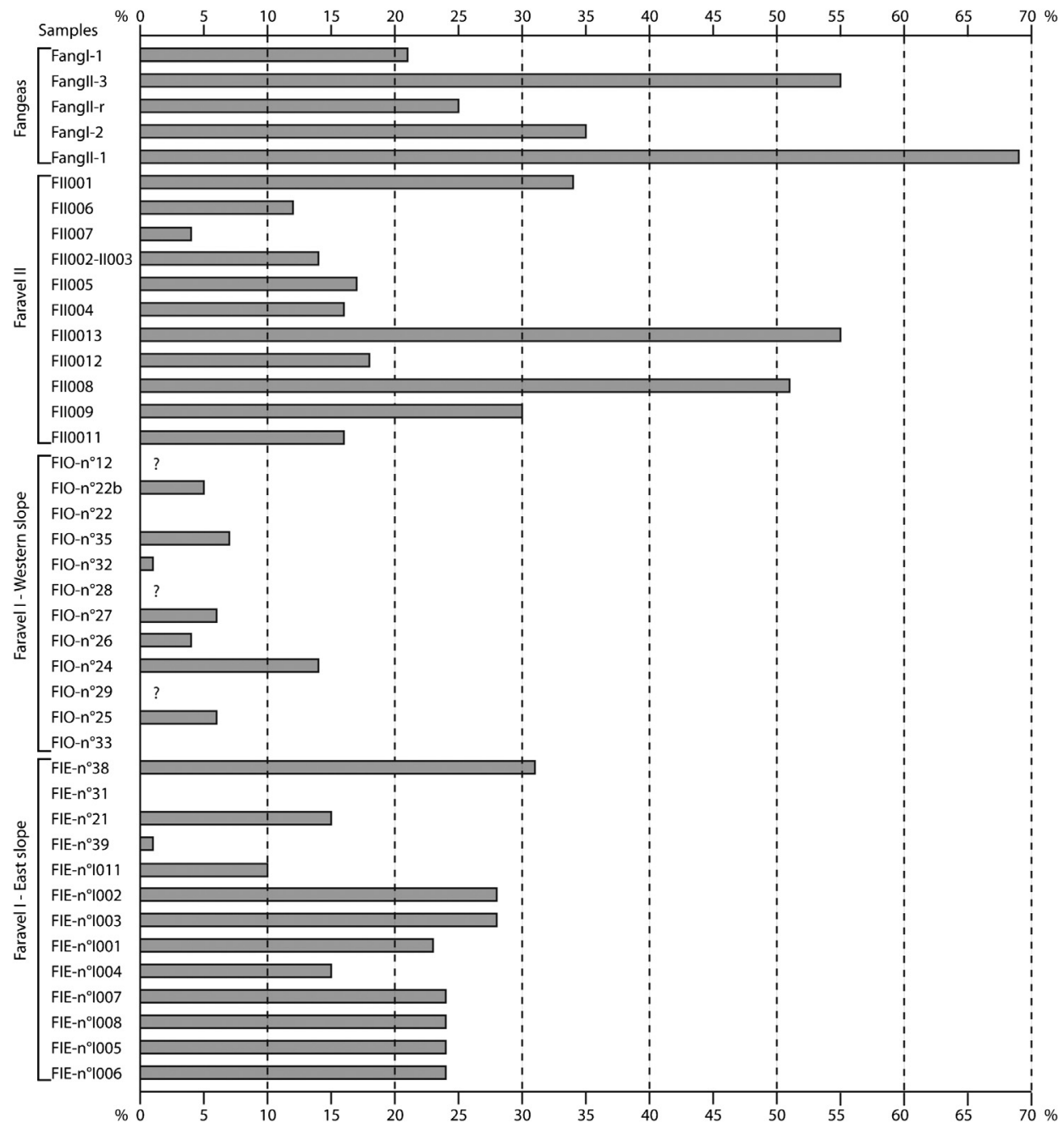

Fig. 6. Bar chart of charcoal frequencies contaminated by fungi in the different samples.

Pinus type sylvestris. It has very low frequencies, often less than $5 \%$. The taxon P. cembra/type sylvestris and taxon Pinus cf. cembra does not refer to a botanical type but to an anatomical uncertainty. Indeed, the microfibrils produced by compression wood can hinder the observation of the ray tracheid walls of pine, which are otherwise easy to distinguish.

Anthracological spectra are almost exclusively dominated by tall subalpine conifers, which is normal given the altitude of the site.

\subsection{Physiological condition of the wood}

Almost all samples (90\%) contained charcoal infested with carbonized mycelium filaments (Fig. 6). In $46 \%$ of these samples, rates from $10 \%$ to $20 \%$ of charcoal infested by mycelium was observed, with $15 \%$ of the samples exceeding $30 \%$ infested charcoal. The frequency of hyphae in woody tissues is low to moderate. Cases of major alteration to the microstructure being caused by parasites are very rare. This data suggests a marginal use of dead wood and a wood storage phase (healthy cut wood) for drying.

\subsection{Morphology of wood selected for firesetting}

Compression wood was detected in almost all samples, but its proportions are not very high (Fig. 7). In about half of the samples, rates of $10 \%$ and more charcoal with compression wood was

Table 1

Table of radiocarbon dates.

\begin{tabular}{|c|c|c|c|c|c|c|c|c|}
\hline Lab. $\mathrm{N}^{\circ}$ & Site & Sector & Mining work & Level & Type & Taxa & Date BP & cal AD (95.4\% prob.) \\
\hline Ly-13466 & Fangeas & Fang-II & Great Pit/gallery & Soil & Charcoal (10 g) & Larix decidua/Picea abies & $895 \pm 30$ & $1040-1215$ \\
\hline Ly-13467 & Fangeas & Fang-II & Great Pit/entry & Soil & Charcoal (10 g) & Larix decidua/Picea abies & $955 \pm 30$ & $1022-1155$ \\
\hline Ly-13465 & Fangeas & Fang-I & Great Well & US 4 & Charcoal (10 g) & Larix decidua/Picea abies & $966 \pm 35$ & $1014-1160$ \\
\hline Ly-13464 & Fangeas & Fang-I & Great Well/search & 1 & Charcoal (10 g) & Pinus cembra & $1055 \pm 35$ & $895-1027$ \\
\hline Ly-13002 & Faravel & FI-SE & Gallery 3 & US 2 & Charcoal (10 g) & Larix decidua/Picea abies & $780 \pm 35$ & $1186-1284$ \\
\hline Ly-13003 & Faravel & FI-SO & West Pit & US 5 & Charcoal (10 g) & Larix decidua/Picea abies & $940 \pm 35$ & $1021-1173$ \\
\hline Ly-13004 & Faravel & FI-SO & West Pit & US 6 & Charcoal (10 g) & Larix decidua/Picea abies & $1000 \pm 35$ & $975-1155$ \\
\hline Ly-13005 & Faravel & FII & Fire level & US 6 & Charcoal (10 g) & Larix decidua/Picea abies & $1085 \pm 35$ & $892-1018$ \\
\hline Poz-20599 & Faravel & FI-SO & Amont trench & US 11 & Charcoal $(0.2 \mathrm{~g})$ & Juniperus & $890 \pm 30$ & $1041-1217$ \\
\hline
\end{tabular}




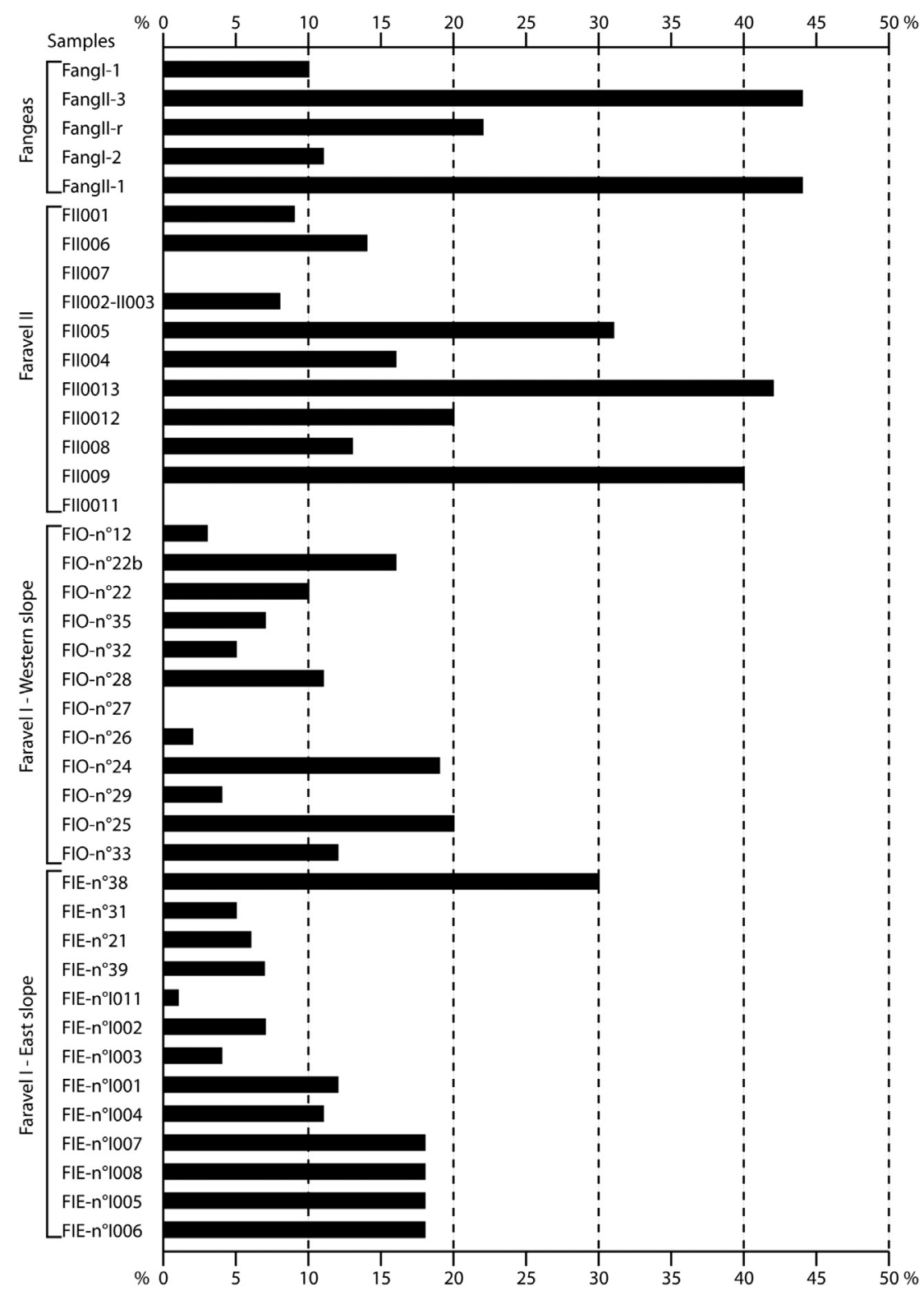

Fig. 7. Bar chart of charcoal frequencies with compression wood in the different samples.

observed, with only five samples exceeded $40 \%$. Compression wood is not unusually overrepresented.

\section{Discussion}

\subsection{Perspectives on palynological, archaeological and} anthracological data

For the southern French Alps, numerous studies of pollen and macro-remains preserved in various soils types has highlighted the evolutionary history of vegetation during the Holocene and its variability from one valley to another (Ali et al., 2004; de Beaulieu et al., 1994; Court-Picon et al., 2005; Kharbouch, 1996; Talon et al., 1998). This variability associated to the plant diversity characterises the mosaic of south Alpine landscapes. In our study area, the joint contributions of archaeology and palaeoenvironmental analyses have already widened our knowledge of the subalpine medieval landscape (Py and Durand, 2010; Segard, 2009; Walsh, 2005; Walsh and Mocci, 2003; Walsh and Richer, 2006). The aforementioned references are important to the current study because they give precious comparative data on vegetation and settlement history. In particular, layers synchronous to the 10th century horizon are situated between 15 and $16 \mathrm{~cm}$ deep in zone 4 of the palynological diagram from the peat area at Fangeas, located near the mining district (Segard, 2009; Walsh and Richer, 2006). They are characterized by a downward shift of the pine curve, the decline of the Arolla pine, the more regular occurrence of Ericaceae and by the significant expansion of larch forest. All pollen indicators suggest the start of a clearing phase during this period, probably related to the sudden return to agropastoral and grazing activities. The beginning of this phase coincides with a fire episode located in the filling up of Faravel II which has been dated to the 10th century. Although a natural cause cannot be ruled out completely, its origin could be correlated with the extension or maintenance by fire of agropastoral subalpine soils (Barbero et al., 1990; Talon, 2010; Touflan et al., 2010). Mining anthracology completes the pollen records where larch is underrepresented due to its very low airborne pollen transport capacity (Kharbouch, 2000). For fifteen 
years, pedoanthracology has contributed to the reassessment of its place in the subalpine and timberline woodland of the Southern Alps during the postglacial period (Ali et al., 2003, 2005; Talon, 2010; Talon et al., 1998). It is also the case for mountain pines. Divergence of pollen and plant macro-remains data can be explained by the lag between the altitudinal boundary of pollenproducing trees and the limit for potential development of woody species (Ali et al., 2003; Carcaillet et al., 1998). Indeed, studies undertaken in the alpine tundra show that trees group together into isolated patches of vegetation and their reproduction is primarily asexual (Tranquilini, 1979). These tree groups that do not produce pollen cannot be apprehended by palynology.

At Faravel, in the mines distribution area, at an altitude of 1970$2150 \mathrm{~m}$, anthracological and palynological data substantiates the hypothesis of a woodland pasture environment with a tree layer dominated by larch associated with a minority of Arolla Pine in the period before $1000 \mathrm{AD}$.

Around the High Middle Ages, palynology documents the regular occurrence of cereal pollen grains, the precipitous drop of pine and the expansion of Poaceae, the latter culminating at nearly $70 \%$ of the pollen sum (Walsh and Richer, 2006). Arolla pine is virtually eliminated while larch successfully colonises areas with less human impact such as poor soils unfit for human activity. Indicators of pastoralism suggest regular grazing activity and the maintenance of pastures. Furthermore, archaeology confirms the development of agropastoral and grazing structures in the Fangeas dell and on the Faravel plateau (Mocci et al., 2005; Walsh and Mocci, 2003; Walsh et al., 2007). This sequence is thus characterised by several methods of highlighting high mountainous resources: pastoral husbandry, mountain agriculture and metal extraction. This combination of activities is the cause of the severe deforestation that led to the establishment of open landscape maintained by mountain communities and characterised by high altitude meadows, the extreme reduction of larch forest and the extension of heathland.

\subsection{Area of firewood supply and forest management for mining}

Before the year 1000 , the timbershed for mining was strictly local (Figs. 5 and 8). Indeed, the fire level spectra are almost identical to the spectra associated with the mining of ore at Faravel II (Fig. 5). Larch constitutes approximately $80 \%$ of woodlands present at an altitude of $2070 \mathrm{~m}$. This taxon is associated with Arolla pine (14.9\%). In the anthracological diagram, juniper and ash are witnesses of the opening of the forest corroborated by palynologic data. Between the year 1000 and the late 12th century, the anthracological spectra indicate an increase in the frequency of larch which forms over $90 \%$ of mining fuel wood. The frequencies of the Arolla pine fall to below 5\%. Within the altitudinal limits of the range of principal works (1970-2150 m alt.), miners harvested fuel wood almost exclusively on the north-facing massifs where larch, typical of fresh and bare soils, developed at the expense of the less dynamic Arolla pine (Bono and Barbero, 1971). The intense operational phase of Fangeas and Faravel I sites that occurred from the second half of the 11th and the first half of the 12th century, was accompanied by a temporary increase in Arolla pine proportions, more significant at Faravel I. This phase could indicate an extension of the timbershed towards stations situated from 2100 to $2200 \mathrm{~m}$ altitude, to even beyond where the Arolla pine was able to survive in the form of little isolated patches of vegetation (Fig. 8) (Talon, 2010; Touflan and Talon, 2009). The occurrence of the Scots pine type, particularly at Faravel I (West pit), supports this hypothesis. Indeed, the flora associated with this taxon suggests the presence of $P$. uncinata, a subalpine pine, rather than the Scots pine, a mountain specie. The atypical spectrum of the upstream trench, dating to the second half of the 11th century to the late 12th century, highlights this extension towards the south-facing side. This marginal harvest of woody shrubs is limited to superficial scraping. It explains the diagram transformations and confirms the open and degraded character of timberline formation and the extension of juniper heathland.

The anthracological spectra of the first half of the 13th century show a clear dichotomy with the spectra of the 10th and 11th 12th centuries (Fig. 5). The fuel wood is dominated by the Arolla pine mixed with larch and to a lesser extent with Scots pine type. At the time, the pressure on woodlands at an altitude between 1970 and $2150 \mathrm{~m}$ was not reduced as shown by the archaeological and palynological data. Therefore, the hypothesis of Arolla pine regeneration is questionable. Pastoral pressure increases during High Middle Ages, consequently Arolla pine regeneration seems unlikely, except at high altitudes or in inaccessible areas (ravines, rocky barriers). One should instead consider a wood supply in treeline isolated patches of vegetation where the Arolla pine associated with Scots pine type ( $c f$. uncinata) and larch was able to survive. The miners' harvesting area may have extended to very high altitudes. Indeed, the survival of the Arolla pine in the High Middle Ages has been testified in altitudinal stations on the other side of the ridge separating the basin of the Drac with the Durance, in sites of pastoral huts at $2100-2350 \mathrm{~m}$ altitude. In several sites, charcoals sampled in occupation layers are dominated by Arolla pine associated to Scots pine type and larch (Py and Durand, 2010). In addition, pedoanthracology has revealed the widespread presence of Arolla pine and larch charcoal from the mid-Holocene until the modern period in the soils of the internal southern French Alps found at $1950-2600 \mathrm{~m}$ altitude. Between 2200 and $2400 \mathrm{~m}$ altitude, it is most often the Arolla pine charcoal which dominates (Ali et al., 2003; Talon, 2010; Talon et al., 1998). Consequently, the upper altitudinal limit of the miners' harvesting area in the 13th century can be reasonably situated at approx. $2400 \mathrm{~m}$ altitude, perhaps slightly higher (Fig. 8). This fact must be correlated with a lowering of the upper limit of the dense forest dominated by larch at least $100 \mathrm{~m}$ below the first mines, that is to say, about $1850 \mathrm{~m}$ a.s.l. Indeed, the palynological diagram of Fangeas reveals that the larch and Arolla pine curves stoped around the XIIIth century. We think that it is the absence of tree around the mines (1950-2150 m) that led the miners to search for trees in the high altitudinal areas. Thus, the disappearance of larch pollen in the palynological diagram associated with the enlargement of wood supply area towards the mountain summits imply a lowering of the upper limit of the larch forest to below the line of $1950 \mathrm{~m}$ a.s.l.

To meet their great need in wood, miners selected the most prevalent subalpine and timberline conifers in their timbershed. Their use of shrubs (heathland) was extremely marginal. Roots have not been identified. In the Austrian Alps, comparable elements were highlighted. Dendrological and dendrochronological analysis of charcoals from a prehistoric pit reveals also a preferential selection of the most prevalent conifers species surrounding the pit for firesetting. In addition, the results suggest that fuel wood was mainly processed from stem wood (Pichler et al., 2011). Our results shed new light on this last point. The low frequencies of compression wood observed do not support the hypothesis of a preferential selection of certain parts of the tree (curved branches, branches, eccentric trunks) after felling to produce mining firewood. Indeed, the parts of the tree containing high proportions of compression wood are generally of less interest than the parts made of normal wood for timber and especially for pieces of wood of great length (Altaner et al., 2009). Their mechanical properties are different and they do not behave the same way during the drying process. But, the proportion of reaction wood in our samples indicates the use of all parts of the felled trees: trunk, limb branches 


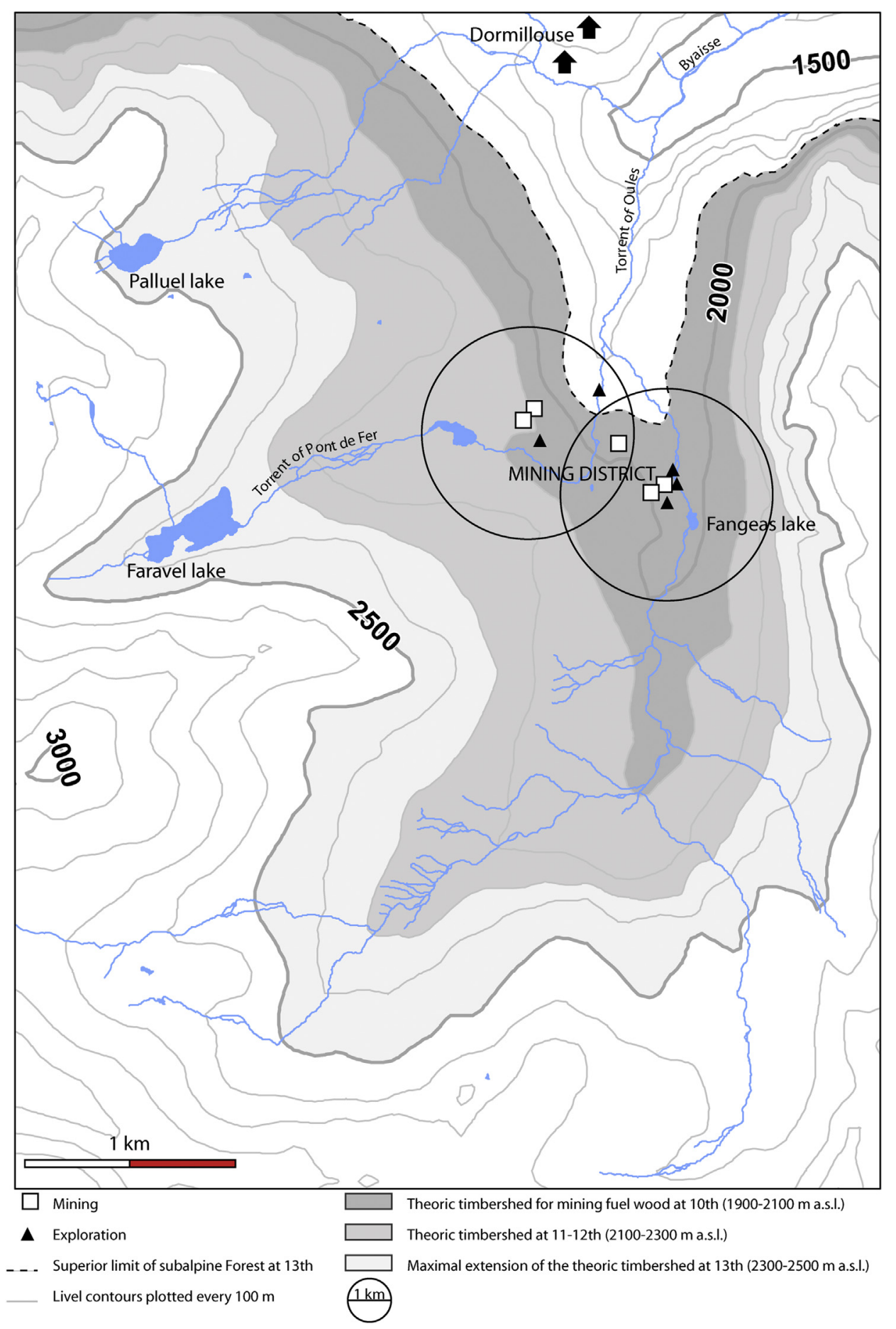

Fig. 8. Location and evolution of the theoretic timbershed for mining fuel wood according to anthracological data.

and including the lower non-linear branches. Evidently, the compression wood wasn't specifically selected, suggesting that the timber wood hadn't been removed, and that all parts of the trees were utilized.

The scarcity of fragments of twigs or trunks with observable tree-ring curves argues for a preferential selection of mature individuals. The circulation of timber was preferably carried out from the tops of the slopes towards the mine. Under these conditions, the most appropriate shifting techniques include sliding (trunks thrown into corridors) and skidding wood with ropes (wood entwined with cords pulled by animals). In the 13th century, wood was probably shifted over several hundred vertical metres and several kilometres. The occurrence of carbonised wood-rot fungi in samples and the modest frequencies of infested charcoal determine a storage phase for wood drying lasting probably more than two years. The average optimum temperatures for fungal growth range from 24 to $32{ }^{\circ} \mathrm{C}$ : when the temperature falls below $10^{\circ} \mathrm{C}$, the cold anesthetises the fungi (Théry-Parisot, 2001). In altitude, the contamination of wood by fungi can take place only during the short summer season. This can nevertheless be sufficient for 
mycelium filaments to invest themselves in the structure. This phase of colonisation takes two years in temperate forests. Decomposition which takes about fifteen years then follows (Théry-Parisot, 2001). In subalpine forests, wood decay can take 70 years (Rayner and Boddy, 1988). The inference is that the phase of fungal colonisation is also longer, that is to say, greater than two years. The climatic conditions of high mountains therefore explain the modest but significant frequencies of infested charcoal within samples and low to moderate mycelium proliferation. These data indicates an anticipation of the dry fuel requirements for the mine. The data set and their corresponding interpretations contribute to nourishing the hypothesis of reasoned and communal management of woodlands for mining in the upper valley of the medieval Byaisse. This hypothesis is supported by similar work undertaken in the nearby Fournel valley and will be published shortly.

\section{Conclusions}

The anthracological study of the Faravel subalpine district in the upper valley of the Byaisse validates the archaeobotanical potential of charcoal mining. At high spatial and chronological resolution, the study reveals the way wood supplies were organised in a smallscale area between the 10th and 13th centuries. Discovery of the first mineralised outcrops occurs during the 10th century. The timber cut for logs comes from subalpine woodlands situated near to the site which are dominated by larch associated with Arolla pine, a specie now rare under natural conditions. Taxa and their proportions characterise a woodland pasture environment conducive to agropastoral activities. Between the 11th and 12th centuries, the major exploitation phase of the ore veins at Fangeas and Faravel coincides with the peak of the medieval Alpine economy, as testified in the Upper Durance by archaeology and palynology. At this time, the charcoal deposits document the disappearance of the Arolla pine in its optimal distribution area, as well as the increase in heathlands and the increase in larch, a pioneer species, in the least impacted or restricted areas. In a cyclical manner, anthracology indicates an extension of the harvesting area in the timberline zone where the Arolla pine, an altitudinal specie, manages to remain. In the 13th century, a subalpine agropastoral over-exploitation crisis led the miners, in search of trees, to source their supply exclusively from the timberline isolated patches of vegetation. The consequence of this evolution was probably a lowering of the upper limit of the subalpine larch forest to at least 100 m below the 1950 $1900 \mathrm{~m}$ altitude line. In addition, medieval mining activity spread over several centuries does not seem to be the only cause of subalpine deforestation, but nevertheless represents an additional pressure on a heavily mined area in the High Middle Ages.

\section{Acknowledgements}

The current study was financially supported by the Regional Archaeological Service of PACA (région Provence-Alpes-Côte d'Azur) and by the Ministry of Culture. Four datations were financed by the project "ACI-Savoir brûler" coordinated by Aline Durand, LA3M ex LAMM, University of Aix-Marseilles. One datation (AMS) was financed by the project GDR Juralp piloted by Florence Mocci, CCJ, University of Aix-Marseilles, Marc Desmet, Edytem, University of Savoy and Michel Magny, University of Besançon. We thank the CNRS laboratory LA3M ex LAMM directed by Henri Amouric, University of Aix-Marseilles, and the Cultural Service of L'Argentière-La Bessée, directed by Ian Cowburn, for their scientific and logistic support. We are grateful to Christine Oberlin, responsable of the datation radiocarbon center of University of Lyons 1, for her kind cooperation on radiocarbon datation issues. Further thanks go to Sylvain Burri, LA3M ex LAMM, University of Aix-
Marseilles, Gabriel Munteanu, TRACES, University of Toulouse 2Le Mirail, and to all the volunteers for their contribuation to archaeological excavations. We would also like to thank Maxence Segard, Archeodunum SA, and Philippe Leveau, University of AixMarseilles, for archaeological and geochimical discussions. We are grateful to Jean-Paul Métailié, GEODE, University of Toulouse II-Le Mirail, Kevin Walsh, University of York and Ian Cowburn for their helpful corrections of the manuscript.

\section{References}

Ali, A.A., Carcaillet, C., Guendon, J.-L., Quinif, Y., Roiron, P., Terral, J.-F., 2003. The early Holocene treeline in the southern French Alps: new evidence from travertine formations. Global Ecology and Biogeography 12, 411-419.

Ali, A.A., Carcaillet, C., Talon, B., Roiron, P., Terral, J.-F., 2005. Pinus cembra L. (arolla pine), a common tree in the inner French Alps since the early Holocene and above the present tree line: a synthesis based on charcoal data from soils and travertines. Journal of Biogeography 32, 1659-1669.

Ali, A.A., Guendon, J.-L., Terral, J.-F., Roiron, P., 2004. Subalpine vegetation dynamics in the southern inner French Alps (Queyras Massif) during the Holocene: evidence from plant imprints and charcoal preserved in travertine sequences. Arctic, Antarctic and Alpine Research 36 (1), 42-48.

Altaner, C.M., Tokareva, E.N., Wong, J.C.T., Hapca, A.I., McLean, J.P., Jarvis, M.C., 2009 Measuring compression wood severity in spruce. Wood Science and Technology 43, 279-290.

Ancel, B., 2010. Les anciennes mines métalliques des Alpes du Sud: bilan diachronique. In: Tzortzis, S., Delestre, X. (Eds.), Archéologie de l'espace montagnard: confrontation d'expériences européennes, Archéologie de la montagne européenne, Actes de la table ronde internationale de Gap, 29 septembre-1er octobre 2008. Errance, Paris, pp. 293-300.

Ancel, B., Py, V., Marconnet, Ch, Leleu, V., 2010. Une mine de plomb argentifère dans un environnement montagnard: la mine médiévale du Fournel à l'Argentière-La Bessée (Hautes-Alpes)Mines et métallurgies anciennes du plomb dans leurs environnements, actes du colloque international de Florac, 8-10 septembre 2008. ArcheoSciences, Revue d'archéométrie vol. 34, 203-220.

Badal, E., 2004. Análisis antracológico de los restos del fuego doméstico del abrigo de los Baños (Ariño, Teruel). In: Utrilla, P., Rodanés, J.M. (Eds.), Un asentamiento epipaleolítico en el valle del Río Martín. El Abrigo de los Baños (Ariño, Teruel) Monografías Arqueológicas 39. Universidad de Zaragoza, pp. 63-74.

Barbero, M., Bonin, G., Loisel, R., Quézel, P., 1990. Changes and disturbances of forest ecosystems caused by human activities in the western part of the mediterranean basin. Vegetatio $87,151-173$.

de Beaulieu, J.-L., 1977. Thesis. Contribution pollenanalytique à l'histoire tardiglaciaire et holocène de la végétation des Alpes méridionales françaises. University Aix-Marseille III, France, p. 358.

de Beaulieu, J.-L., de Richard, H., Ruffaldi, P., Clerc, J., 1994. History of vegetation, climate and human action in the French Alps and the Jura over the last 15000 years. In: Lotter, A.F., Ammann, B. (Eds.), 1994. Dissertationes Botanicae, vol. 234, pp. 253-275.

Berg, B.I., 1992. Les techniques d'abattage à Kongsberg (Norvège) du XVII ${ }^{\mathrm{e}}$ au XIX siècle: pointerolle, travail au feu et tir à la poudre. In: Les techniques minières de l'Antiquité au XVIIIe s., Colloque international du $113^{\text {ème }}$ congrès national des sociétés savantes, Strasbourg 1988. CTHS, Paris, pp. 55-76.

Bono, G., Barbero, M., 1971. À propos des cembraies des Alpes cottiennes italiennes, maritimes et ligures. Allionia 17, 97-120.

Bronk Ramsey, C., 2009. Bayesian analysis of radiocarbon dates. Radiocarbon 51 (1), $337-360$.

Carcaillet, C., Talon, B., Barbero, C., 1998. Pinus cembra et incendies pendant l'Holocène, $300 \mathrm{~m}$ au-dessus de la limite actuelle des arbres dans le massif de la Vanoise (Alpes du nord-ouest). Écologie 29, 277-282.

Castelletti, L., Castiglioni, E., 1993. Resti lignei del XII-XIII secolo dalla miniera « VIII Sfera ». In: Milano e la Lombardia in età comunale secoli XI-XIII, MilanoPalazzo Reale, 15 aprile-11 luglio, 1993, Silvana, pp. 239-242.

Chabal, L., 1997. Forêts et sociétés en Languedoc (Néolithique final, Antiquité tardive). L'anthracologie, méthode et paléoécologie. DAF 63, Editions de la Maison des Sciences de l'Homme, Paris, p. 189.

Court-Picon, M., Buttler, A., de Beaulieu, J.-L., 2005. Modern pollen-vegetation relationships in the Champsaur valley (French Alpes) and their potential in the interpretation of fossil pollen records of past cultural landscapes. Review of Palaeobotany and Palynology 135, 13-39.

Dubois, $\mathrm{Cl}$, 1996. L'ouverture par le feu dans les mines: histoire, archéologie et expérimentation. Revue d'archéométrie 20, 33-46.

Greguss, P., 1959. Holzanatomie der Europäischen Laubhölzer und Sträucher. Akadémiai Kiadò, Budapest, p. 330.

Hapca, A., 2004. Distribution du bois de compression dans l'arbre en relation avec sa forme externe. Application à l'picéa commun (Picea abies Karst.). Thesis. Sciences forestières et du bois, ENGREF, Nancy-Champenoux, p. 200.

Heiss, A.G., Oeggl, K., 2008. Analysis of the fuel wood used in Late Bronze Age and Early Iron Age copper mining sites of the Schwaz and Brixlegg area (Tyrol, Austria). Vegetation History and Archaeobotany 17, 211-221.

Jacomet, S., Kreuz, A., 1999. Archäobotanik. Ulmer, Stuttgart, p. 368 
Kharbouch, M., 1996. Paléoenvironnement végétal de la région du Mont Bégo (Tende, Alpes Maritimes) depuis 15000 ans. Contributions palynologiques et interprétations paléoclimatiques. Thesis. Institut de Paléontologie Humaine Museum National d'Histoire Naturelle, Paris, p. 252

Kharbouch, M., 2000. Variations altitudinales de quelques taxons végétaux dans les Alpes du Sud durant le Tardiglaciaire et l'Holocène. Quaternaire $11\left(n^{\circ} 3 / 4\right)$, 231-242.

Ludemann, T., 2010. Fuel wood economy of historical mining in the black forest (Germany). In: Anreiter, P., Goldenberg, G., Hanke, K., Krause, R., Leitner, W., Mathis, F., Nicolussi, K., Oeggl, K., Pernicka, E., Prast, M., Schibler, J., Schneider, I., Stadler, H., Stöllner, T., Tomedi, G., Tropper, P. (Eds.), Mining in European History and Its Impact on Environment and Human Societies. Proceedings for the 1st Mining in European History-Conference of the SFB-HIMAT, 12.-15. November 2009, Innsbruck, Conference Series, pp. 183-186.

Mocci, F., Tzortzis, S., Palet Martinez, J.M., Segard, M., Walsh, K., 2005. Peuplement, pastoralisme et modes d'exploitation de la moyenne et haute montagne depuis la Préhistoire dans le Parc National des Écrins (vallées du haut Champsaur et de Freissinières, Hautes-Alpes). In: Verdin, F., Bouet, A. (Eds.), Territoires et paysages de l'âge du Fer au Moyen Âge. Mélanges offerts à Philippe Leveau. Presses universitaires de Bordeaux, pp. 197-212.

Moskal-del Hoyo, M., Wachowiak, M., Blanchette, R.A., 2010. Preservation of fungi in archaeological charcoal. Journal of Archaeological Science 37, 2106-2116.

Nakagawa, T., 1998. Études palynologiques dans les Alpes françaises centrales et méridionales: histoire de la végétation tardiglaciaire et holocène. Thesis. University of Aix-Marseille III, France, p. 211.

Ozenda, P., 1985. La végétation de la chaîne alpine dans l'espace montagnard européen. Paris, Masson, p. 331.

Pichler, T., Goldenberg, G., Hanke, K., Kovács, K., Thurner, A., Nicolussi, K., 2011. Charcoals from a prehistoric fire-set pit in the Austrian Alps - dendro-dates, wood demand and forest utilization. In: Badal, E., Carrión, Y., Grau, E., Macías, M., Ntinou, M. (Eds.), 5th International Meeting of Charcoal Analysis, The Charcoals as Cultural and Biological Heritage, Saguntum Extra 11, València, pp. 135-136.

Py, V., 2006. Mine charcoal deposits: methods and strategies. The medieval Fournel silver mines in the Hautes-Alpes (France). In: Dufraisse, A. (Ed.), Charcoal Analysis: New Analytical Tools and Methods for Archaeology, Papers from the Table-Ronde Held in Basel, 14-15 Octobre 2004. BAR International Series S 1483. Archaeopress, Oxford, pp. 35-46.

Py, V., 2009. Mine, bois et forêt dans les Alpes du Sud au Moyen Âge. Thesis. In: Approches archéologique, bioarchéologique et historique, vol. 3. University of de Provence Aix-Marseille I, France, 1-2, 1332 p., 3, 116 p.

Py, V., 2010. Techniques et usages du bois des mineurs à Faravellum aux XIe-XIIIe s (Freissinières, Hautes-Alpes). In: Delhon, Cl., Théry-Parisot, I., Thiébault, S. (Eds.), Des hommes et des plantes. Exploitation du milieu et des ressources végétales de la Préhistoire à nos jours, actes des $\mathrm{XXX}^{\mathrm{e}}$ Rencontres Internationales d'Archéologie et d'Histoire d'Antibes, 22-24 Octobre 2009, Palais des Congrès de Juan-les-Pins, Antibes, Éditions APDCA, pp. 293-321.

Py, V., Ancel, B., 2007. Exploitation des mines métalliques de la vallée de Freissinières (Hautes-Alpes, France): Contribution à l'étude de l'économie sud-alpine aux IX ${ }^{\mathrm{e}}-\mathrm{XIII}^{\mathrm{e}}$ siècles. In: Della Casa, P., Walsh, K. (Eds.), Actes de la session montagne «Interpretation of sites and material culture from mid-high altitude mountain environments ", colloque de l'European Association of Archaeologistes, Lyon, septembre 2004. Preistoria Alpina vol. 42, 83-93.

Py, V., Durand, A., 2010. Évolution des écosystèmes et des pratiques agrosylvopastorales et minière pour la production de bois de feu dans le haut Champsaur et la haute Durance (France) de l'âge du Bronze ancien au XVI ${ }^{\mathrm{e}}$ siècle. In: Stzortzis, S., Delestre, X. (Eds.), Archéologie de l'espace montagnard: confrontation d'expériences européennes, Archéologie de la montagne européenne, Actes de la table ronde internationale de Gap, 29 septembre- ${ }^{\text {er }}$ octobre 2008, Bibliothèque d'Archéologie Méditerranéenne et Africaine, 4, Paris, Errance, pp. 283-292.

Py, V., Ancel, B., Marconnet, C., 2012. De l'usage minier du feu: sources et expérimentations. In: Durand, A. (Ed.), 2012. Des outils, des machines et des hommes, Cahier d'Histoire des Techniques, vol. 8. PUP, pp. 133-153.

Rayner, A.D.M., Boddy, L., 1988. Fungal Decomposition of Wood: its Biology and Ecology. Wiley-Interscience, Chichester, New-York, p. 587.

Reimer, P.J., Baillie, M.G.L., Bard, E., Bayliss, A., Beck, J.W., Blackwell, P.G., Bronk Ramsey, C., Buck, C.E., Burr, G.S., Edwards, R.L., Friedrich, M., Grootes, P.M. Guilderson, T.P. Hajdas, I. Heaton, TJ., Hogg A.G., Hughen, K.A., Kaiser, K.F. Kromer, B., McCormac, F.G., Manning, S.W., Reimer, R.W., Richards, D.A.,
Southon, J.R., Talamo, S., Turney, C.S.M., van der Plicht, J., Weyhenmeyer, C.E., 2009. IntCal09 and Marine09 radiocarbon age calibration curves, $0-50,000$ years cal BP. Radiocarbon 51 (4), 1111-1150.

Schweingruber, F.H., 1978. Mikroskopische holzanatomic: Anatomie microscopique du bois. Institut Fédéral de Recherches Forestières (Suisse), Zürcher AG, Zug, Birsmensdorf, p. 226.

Schweingruber, F.H., 1982. Mikroskopische Holzanatomie, Kommissionsverlag. In: Flück-Wirth, F. (Ed.), Internationale Buchhandlung für Botanik und Naturwissenschaften, $\mathrm{CH}-905$ Teufen AR.

Schweingruber, F.H., 1990. Anatomie Europäischer Hölzer: Anatomie of European Woods. Haupt, Stuttgart, p. 800.

Segard, M. 2009. Les Alpes occidentales romaines. Développement urbain et exploitation des ressources des régions de montagne (Gaule Narbonnaise, Italie, provinces alpines). Bibliothèque d'Archéologie Méditerranéenne et Africaine, 1, , Aix-en-Provence, Errance, p. 285.

Talon, B., 2010. Reconstruction of Holocene high-altitude vegetation cover in the French southern Alps: evidence from soil charcoal. The Holocene 20 (1), 35-44.

Talon, B., Carcaillet, C., Thinon, M., 1998. Études pédoanthracologiques des variations de la limite supérieure des arbres au cours de l'Holocène dans les Alpes françaises. Géographie physique et Quaternaire 52, 193-206.

Téreygeol, F., Dubois, Cl, 2003. Mines et métallurgie carolingiennes à Melle (DeuxSèvres, France): l'apport des charbons de bois archéologiques. Archéologie Médiévale 33, 91-102.

Tessier, L., Beaulieu, J.-L., de Coûteau, M., Édouard, J.-L., Ponel, P., Rolando, C., Thinon, M., Thomas, A., Tobolski, K., 1993. Holocene palaeoenvironments at the Timberline in the French Alps - a multidisciplinary approach. Boreas 22, 244-254.

Théry-Parisot, I., 2001. Économie des combustibles au Paléolithique. CNRS, Paris, p. 195.

Théry-Parisot, I., Chabal, L., Chrzavzez, J., 2010. Anthracology and taphonomy, from wood gathering to charcoal analysis. A review of the taphonomic processes modifying charcoal assemblages, in archaeological contexts. Palaeogeography, Palaeoclimatology, Palaeoecology 291, 142-153

Timberlake, S., 1990. Review of the Historical evidence for the use of firesetting, « early mining in the British Isles ». In: Proceedings of the Early Mining Workshop at Plas Tan y Bwlch Snowdonia National Park Study Centre, 17-19 November, 1989, Plas Tan y Bwlch Occasional Paper, 1, pp. 49-52.

Touflan, P., Talon, B., 2009. Spatial reliability of soil charcoal analysis: the case of subalpine forest soils. Ecoscience 16, 23-27.

Touflan, P., Talon, B., Walsh, K., 2010. Soil charcoal analysis: a reliable tool for spatially precise studies of past forest dynamic: a case study in the French southern Alps. The Holocene 20 (1), 45-52.

Tranquilini, W., 1979. Physiological Ecology of the Alpine Timberline: Tree Existence at High Altitudes with Special Reference to the European Alps. In: Ecological Studies, vol. 31. Springer-Verlag, Berlin, New-York, pp. 119-131.

Vernet, J.-L., Ogereau, P., Figueiral, I., Machado Yanes, C., Uzquiano, P., 2001. Guide d'identification des charbons de bois préhistoriques et récents, Sud-Ouest de l'Europe: France, Péninsule ibérique et Îles Canaries. CNRS, Paris, p. 395.

Walsh, K., 2005. Risk and marginality at high altitudes: new interpretations from fieldwork on the Faravel Plateau, Hautes-Alpes. Antiquity 79, 289-305.

Walsh, K., Mocci, F., 2003. 9000 ans d'occupation du sol en moyenne et haute montagne: la vallée de Freissinières dans le Parc national des Écrins (Freissinières, Hautes-Alpes). Archéologie du Midi Médiéval 21, 185-198.

Walsh, K., Mocci, F., Palet-Martinez, J.M., 2007. Nine thousand years of human/ landscape dynamics in a high altitude zone in the southern French Alps (Parc National des Écrins, Hautes-Alpes). In: Della Casa, P., Walsh, K. (Eds.), Actes de la session montagne "Interpretation of sites and material culture from mid-high altitude mountain environments », colloque de l'European Association of Archaeologists, Lyon, septembre 2004. Preistoria Alpina vol. 42, 9-22.

Walsh, K., Richer, S., 2006. Attitudes to altitude: changing meanings and perceptions within a «marginal » Alpine landscape - the integration of palaeological and archaeological data in a high altitude landscape in the French Alps. World Archaeology 38, 436-454.

Wegmüller, S., 1977. Pollenanalytische Untersuchungen zur Spät- und Postgazialen Vegetationgeschichte der französischen Alpen. Thesis, Berne, p. 178.

Weisgerber, G., Willies, L., 2001. The use of fire in prehistoric and ancient mining: firesetting. Paléorient 26/2,131-149. CNRS.

Willies, L., 1994. Firesetting technology. Bulletin of the Peak District Mines Historical Society $12(3), 1-8$ 